\title{
OPEN Lateral hypothalamus involvement in control of stress response by bed nucleus of the stria terminalis endocannabinoid neurotransmission in male rats
}

\author{
Lucas Gomes-de-Souza ${ }^{1,2}$, Willian Costa-Ferreira ${ }^{1,2}$, Michelle M. Mendonça ${ }^{3}$, \\ Carlos H. Xavier ${ }^{3}$ \& Carlos C. Crestani ${ }^{1,2,4}$
}

The endocannabinoid neurotransmission acting via local $\mathrm{CB}_{1}$ receptor in the bed nucleus of the stria terminalis (BNST) has been implicated in behavioral and physiological responses to emotional stress. However, the neural network related to this control is poorly understood. In this sense, the lateral hypothalamus (LH) is involved in stress responses, and BNST GABAergic neurons densely innervate this hypothalamic nucleus. However, a role of BNST projections to the LH in physiological responses to stress is unknown. Therefore, using male rats, we investigated the role of LH GABAergic neurotransmission in the regulation of cardiovascular responses to stress by $\mathrm{CB}_{1}$ receptors within the BNST. We observed that microinjection of the selective $C B_{1}$ receptor antagonist $A M 251$ into the BNST decreased the number of Fos-immunoreactive cells within the LH of rats submitted to acute restraint stress. Treatment of the BNST with AM251 also enhanced restraint-evoked tachycardia. Nevertheless, arterial pressure increase and sympathetically-mediated cutaneous vasoconstriction to restraint was not affected by $\mathrm{CB}_{1}$ receptor antagonism within the BNST. The effect of AM251 in the BNST on restraint-evoked tachycardia was abolished in animals pretreated with the selective $\mathrm{GABA}_{A}$ receptor antagonist SR95531 in the LH. These results indicate that regulation of cardiovascular responses to stress by $C_{1}$ receptors in the BNST is mediated by GABAergic neurotransmission in the LH. Present data also provide evidence of the BNST endocannabinoid neurotransmission as a mechanism involved in LH neuronal activation during stressful events.

The bed nucleus of the stria terminalis (BNST) has been implicated in physiological and behavioral responses to stress ${ }^{1-3}$. Regarding the cardiovascular responses, previous studies demonstrated that BNST modulates the blood pressure and heart rate (HR) increases caused by both unconditioned and conditioned stressfull stimuli, as well as by non-aversive environmental challenges (e.g., exercise) $)^{4-6}$.

Several neurochemical mechanisms have been implicated in the BNST control of stress responses ${ }^{1,7}$, including the endocannabinoid system ${ }^{8}$. Indeed, the presence of endocannabinoid receptors and enzymes involved in endocannabinoid synthesis and degradation were identified within the BNST ${ }^{9-15}$. Activation of BNST endocannabinoid neurotransmission during aversive threats was first evidenced by demonstration that systemic administration of a selective $\mathrm{CB}_{1}$ receptor antagonist enhanced BNST neuronal activation evoked by stress ${ }^{16,17}$.

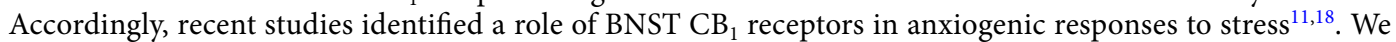
also reported an inhibitory influence of $\mathrm{CB}_{1}$ receptors present in the BNST in tachycardia observed during acute restraint stress ${ }^{13}$. Taken together, these results indicated the BNST endocannabinoid neurotransmission as part of the neural pathway regulating stress responses. However, the neural circuit related to this control is unknown.

\footnotetext{
${ }^{1}$ Laboratory of Pharmacology, School of Pharmaceutical Sciences, São Paulo State University (UNESP), Araraquara, São Paulo, Brazil. ' Joint UFSCar-UNESP Graduate Program in Physiological Sciences, São Carlos, São Paulo, Brazil. ${ }^{3}$ Institute of Biological Sciences, Federal University of Goiás, Goiania, Goiás, Brazil. ${ }^{4}$ Laboratory of Pharmacology, Department of Department of Drugs and Pharmaceutics, School of Pharmaceutical Sciences, São Paulo State University - UNESP, Rodovia Araraquara-Jau Km 01 (Campus Universitário), Campus Ville, Araraquara, SP 14800-903, Brazil. ${ }^{\bowtie}$ email: cccrestani@yahoo.com.br
} 
The BNST is proposed as an important site connecting corticolimbic structures with effector nuclei of physiological and behavioral responses in the hypothalamus and brainstem ${ }^{1-3,7}$. In this sense, the BNST sends dense projections to the lateral hypothalamus $(\mathrm{LH})^{19,20}$. Such as BSNT, the LH also plays a role in physiological and behavioral responses to emotional stress ${ }^{2,21-24}$. Regarding the stress-evoked cardiovascular responses, previous studies documented a role of this diencephalic region controlling cardiovascular responses evoked by both conditioned and unconditioned aversive stimuli ${ }^{25-27}$. The LH has an inhibitory influence in cardiovascular responses to unconditioned stress ${ }^{27}$, which is mediated by a balance of local excitatory and inhibitory inputs. Indeed, local LH treatment with a selective NMDA glutamatergic receptor antagonist enhanced the HR response to restraint $\operatorname{stress}^{27}$, whereas opposite effect was observed following $\mathrm{LH}$ treatment with a selective $\mathrm{GABA}_{\mathrm{A}}$ receptor antagonist ${ }^{28}$.

The majority of neurons within the BNST present a GABAergic phenotype ${ }^{29-32}$. Accordingly, some studies provided evidence of GABAergic inputs within the $\mathrm{LH}$ arising from the BNST ${ }^{33,34}$. These morphofunctional evidence, taken together with evidence stated above of an inhibitory role of LH in tachycardia to restraint ${ }^{27}$, supported the idea that the LH might be part of the neural pathway related to the inhibitory control of restraintevoked tachycardia by BNST endocannabinoid neurotransmission. In this sense, considering recent evidence that regulation of restraint-evoked tachycardia by BNST $\mathrm{CB}_{1}$ receptor is mediated by inhibition of local glutamatergic neurotransmission ${ }^{35}$, we investigated the hypothesis that the antagonism of $\mathrm{CB}_{1}$ receptor within the BNST decreases local neuronal activation within the LH as resulted of increased activation of BNST GABAergic neurons projecting to the HL, which in turn increases $\mathrm{HR}$ response to stress.

Results

Effect of $\mathrm{CB}_{1}$ receptor blockade within the BNST on number of Fos-positive neurons in the $\mathrm{LH}$ of stressed animals. Bilateral microinjection of the selective $\mathrm{CB}_{1}$ receptor antagonist AM251 ( $100 \mathrm{pmol} / 100 \mathrm{~nL} / \mathrm{side}, \mathrm{n}=11$ ) into the BNST decreased the number of Fos-positive cells in the LH following exposure to restraint stress $(\mathrm{t}=4.59 ; \mathrm{df}=17, \mathrm{P}=0.0003)$, when compared to vehicle-treated animals $(100 \mathrm{~nL} / \mathrm{side}$, $\mathrm{n}=8$ ) (Fig. 1). Figure 1 also presents representative coronal sections of the $\mathrm{LH}$ region showing Fos-positive cells of animals subjected to restraint stress that received vehicle or AM251 into the BNST, as well as a representative section indicating the $\mathrm{LH}$ location.

Effect of $\mathrm{GABA}_{\mathrm{A}}$ receptor antagonism in the $\mathrm{LH}$ in changes on arterial pressure and $\mathrm{HR}$ reactivity to acute restraint stress evoked by $\mathrm{CB}_{1}$ receptor blockade in the BNST. Analysis of basal parameters (i.e., pre-stress values) indicated that bilateral microinjections of the $\mathrm{GABA}_{\mathrm{A}}$ receptor antagonist SR95531 (1 pmol/100 nL/side) into the $\mathrm{LH}$ and/or the selective $\mathrm{CB}_{1}$ receptor antagonist AM251 $(100 \mathrm{pmol} / 100 \mathrm{~nL} / \mathrm{side})$ into the $\mathrm{BNST}$ affected mean arterial pressure (MAP) $\left(\mathrm{F}_{(3,24)}=3.3, \mathrm{P}=0.0376\right)$, but without changing $\mathrm{HR}\left(\mathrm{F}_{(3,24)}=0.5, \mathrm{P}=0.7259\right)$ (Table 1). Nevertheless, post-hoc analysis of MAP basal values did not reveal specific differences between the experimental groups $(\mathrm{P}>0.05)$ (Table 1$)$.

Analysis of the time-course curves indicated that acute restraint stress caused a sustained increase on both MAP (time factor: $\mathrm{F}_{(35,840)}=54, \mathrm{P}<0.0001$ ) and $\mathrm{HR}$ (time factor: $\mathrm{F}_{(35,840)}=56, \mathrm{P}<0.0001$ ), (Fig. 2). Two-way ANOVA also indicated effect of BNST and/or LH pharmacological treatments on restraint-evoked HR increase $\left(\mathrm{F}_{(3,24)}=4.0, \mathrm{P}=0.0198\right)$, but without affecting MAP $\left(\mathrm{F}_{(3,24)}=0.4, \mathrm{P}=0.7551\right)$ (Fig. 2$)$. A treatment $\times$ time interaction for $\mathrm{HR}\left(\mathrm{F}_{(105,840)}=2.4, \mathrm{P}<0.0001\right)$ and MAP $\left(\mathrm{F}_{(105,840)}=1.5, \mathrm{P}=0.0042\right)$ was also evidenced. Post-hoc analysis revealed that AM251 into the BNST (saline LH + AM251 BNST group) increased restraint-evoked tachycardiac response $(\mathrm{P}=0.0077)$ (Fig. 2). The effect of AM251 within the BNST on HR increase to restraint stress was inhibited by LH pretreatment with the $\mathrm{GABA}_{\mathrm{A}}$ receptor antagonist (SR95531 LH + AM251 BNST group) $(\mathrm{P}=0.5898)$ (Fig. 2). Post-hoc analyisis did not reveal specific differences between the experimental groups on MAP response $(\mathrm{P}>0.05)$ (Fig. 2).

Analysis of the mean change during the entire restraint period indicated effect of pharmacological treatments on HR increase $\left(\mathrm{F}_{(3,24)}=4.7, \mathrm{P}=0.0103\right)$, but without affecting MAP response $\left(\mathrm{F}_{(3,24)}=0.4, \mathrm{P}=0.7553\right)$ (Fig. 2$)$. Post-hoc analysis revealed that AM251 into the BNST (sal LH + AM251 BNST group) increased the tachycardia to restraint stress $(\mathrm{P}=0.0042)$, and such potentiation effect was absent in animals pretreated with the $\mathrm{GABA}_{\mathrm{A}}$ receptor antagonist into the LH (SR95531 LH + AM251 BNST group) $(\mathrm{P}=0.4760)$ (Fig. 2).

Figure 2 presents representative experimental recordings showing the effect of restraint stress in MAP and $\mathrm{HR}$ in animals that received vehicle or the selective $\mathrm{GABA}_{\mathrm{A}}$ receptor antagonist into the $\mathrm{LH}$, followed by microinjection of vehicle or the $\mathrm{CB}_{1}$ receptor antagonist into the BNST.

Effect of $\mathrm{GABA}_{A}$ receptor antagonism in the $\mathrm{LH}$ in changes on tail skin temperature reactivity to acute restraint stress evoked by $\mathrm{CB}_{1}$ receptor blockade in the BNST. Bilateral microinjections of the $\mathrm{GABA}_{\mathrm{A}}$ receptor antagonist SR95531 (1 pmol/100 nL/side) into the $\mathrm{LH}$ and/or the selective $\mathrm{CB}_{1}$ receptor antagonist AM251 (100 pmol/100 nL/side) did not affect the basal values (i.e., pre-stress level) of tail skin temperature $\left(\mathrm{F}_{(3,24)}=1.9, \mathrm{P}=0.1656\right)$ (Table 1$)$. However, analysis of the time-course curves indicated that acute restraint stress decreased the skin temperature (time factor: $\mathrm{F}_{(6,144)}=53, \mathrm{P}<0.0001$ ) (Fig. 3). Two-way ANOVA did not indicate effect of BNST and/or LH pharmacological treatments on restraint-evoked decrease in tail skin temperature $\left(\mathrm{F}_{(3,24)}=1.8, \mathrm{P}=0.1847\right)$ (Fig. 3), but a treatment $\mathrm{x}$ time interaction was evidenced $\left(\mathrm{F}_{(18,144)}=3.1\right.$, $\mathrm{P}=0.0059)$. Nevertheless, post-hoc analysis did not reveal difference between the experimental groups in restraint-evoked drop in tail skin temperature $(\mathrm{P}>0.05)$ (Fig. 3). Analysis of the mean change during the entire restraint period also did not indicate effect of pharmacological treatments on tail skin temperature response $\left(\mathrm{F}_{(3,24)}=2.9, \mathrm{P}=0.0515\right)$ (Fig. 3). Figure 3 presents representative images showing the tail skin temperature before 


\section{Fos-IR cells in the LH}
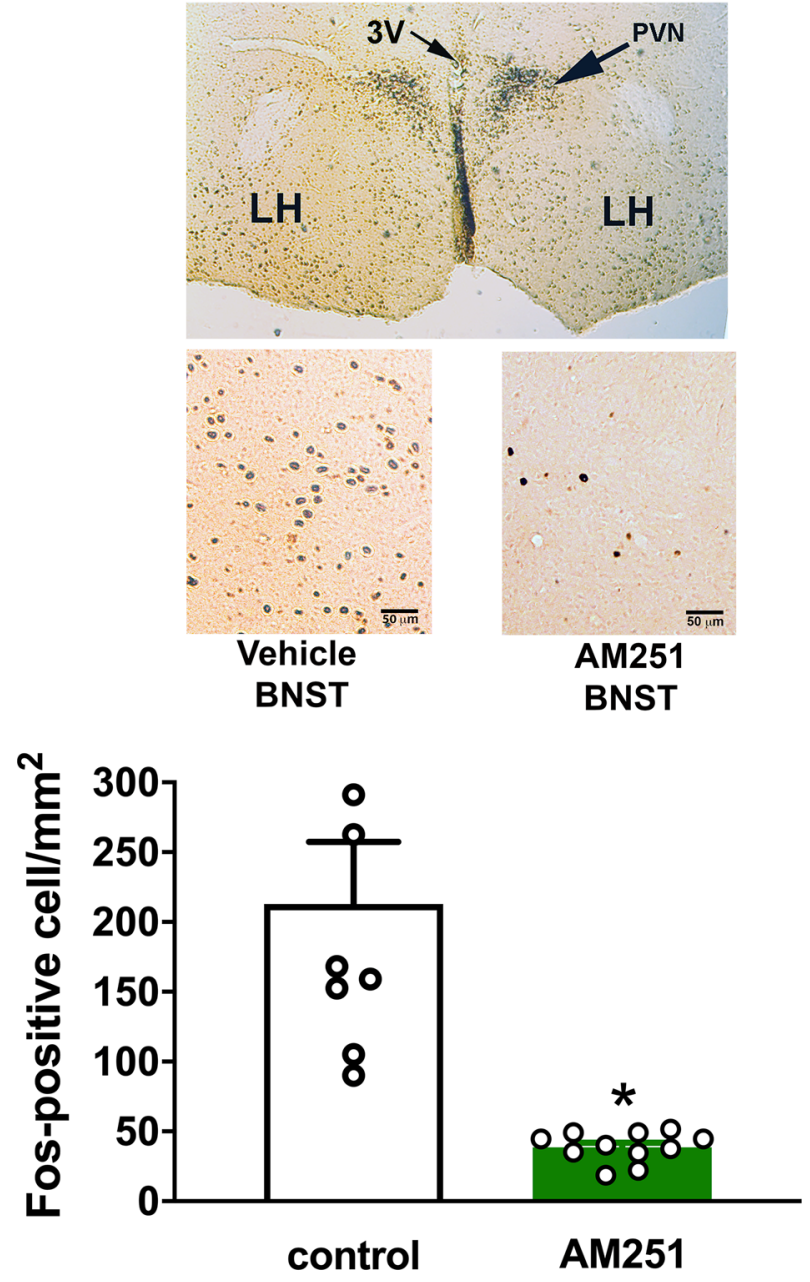

Figure 1. Effect of bed nucleus of the stria terminalis (BNST) treatment with the $\mathrm{CB}_{1}$ receptor antagonist AM251 in the number of Fos-immunoreactive (IR) cells in the LH following exposure to a 60-min session of restraint stress. (Top) Representative coronal sections showing Fos-IR cells in the LH following restraint stress exposure in animals that received bilateral microinjection of vehicle or AM251 into the BNST (bottom), as well as a representative section indicating the $\mathrm{LH}$ location (top). $3 \mathrm{~V}$ third ventricle, $L H$ lateral hypothalamus, $P V N$ paraventricular nucleus of the hypothalamus. (Bottom) Number of Fos-IR cells in the LH following exposure to acute restraint stress in animals treated with vehicle [solution of saline containing 30\% of DMSO (DMSO), 100 $\mathrm{nL}, \mathrm{n}=8$ ] (white bar) or the selective $\mathrm{CB}_{1}$ receptor antagonist AM251 (100 pmol/100 nL, $\left.\mathrm{n}=11\right)$ (green bar) into the BNST. The bars represent the mean \pm SEM. ${ }^{\star} \mathrm{P}<0.05$, Student's $t$ test.

\begin{tabular}{|l|l|l|l|l|}
\hline Groups & $\mathbf{n}$ & MAP $(\mathbf{m m H g})$ & HR $(\mathbf{b p m})$ & T $\left({ }^{\circ} \mathbf{C}\right)$ \\
\hline SAL LH + DMSO BNST & 7 & $109 \pm 2$ & $392 \pm 8$ & $28.7 \pm 0.2$ \\
\hline SAL LH + AM251 BNST & 7 & $111 \pm 3$ & $389 \pm 11$ & $29.1 \pm 0.1$ \\
\hline SR LH+DMSO BNST & 7 & $104 \pm 1$ & $398 \pm 8$ & $29.6 \pm 0.2$ \\
\hline SR LH+ AM251 BNST & 7 & $104 \pm 2$ & $406 \pm 16$ & $28.9 \pm 0.5$ \\
\hline
\end{tabular}

Table 1. Basal parameters of mean arterial pressure (MAP), heart rate (HR) and tail skin temperature (T) after pharmacological treatment of the BNST with the selective $\mathrm{CB}_{1}$ receptor antagonist AM251 (or vehicle) and/or the $\mathrm{LH}$ with the selective $\mathrm{GABA}_{\mathrm{A}}$ receptor antagonist SR95531 (or vehicle). Values are mean \pm SEM, one-way ANOVA. DMSO saline containing 30\% of DMSO, SAL saline, SR SR95531. 
-O- SAL LH+DMSO BNST ㄴ- SR95531 LH+DMSO BNST

- $S A L L H+A M 251 B N S T \rightarrow S R 95531 L H+A M 251 B N S T$
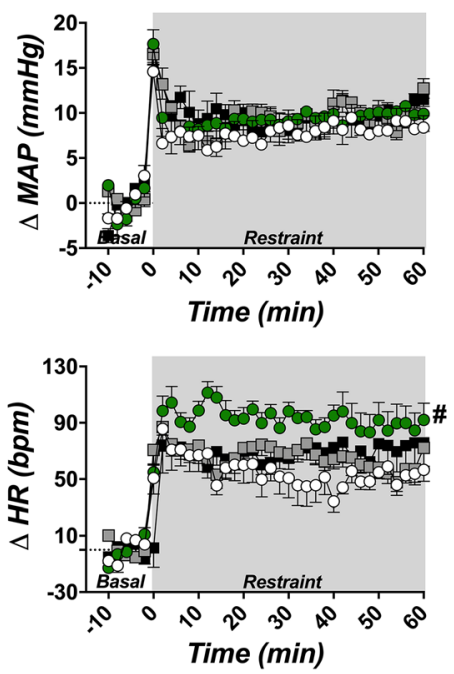

O sal LH + DMSO BNST O SR LH + DMSO BNST

O sal LH + AM251 BNST $\bigcirc$ SR LH + AM251 BNS
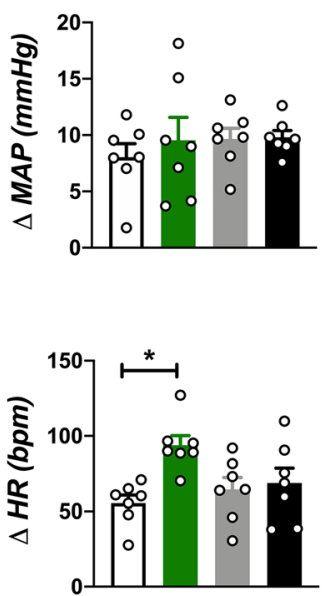
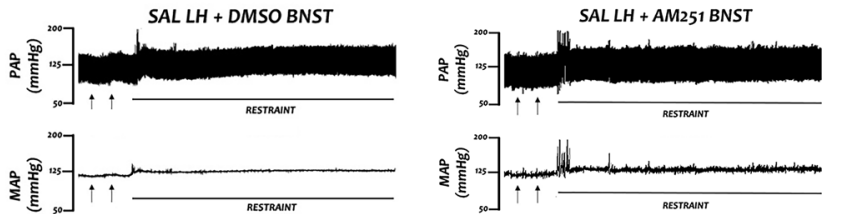

है है

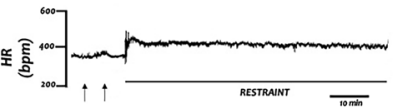

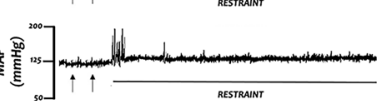

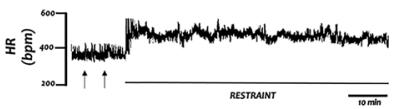

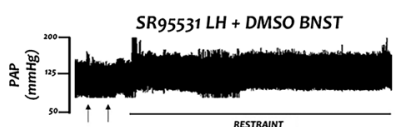
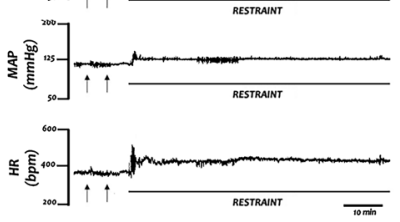
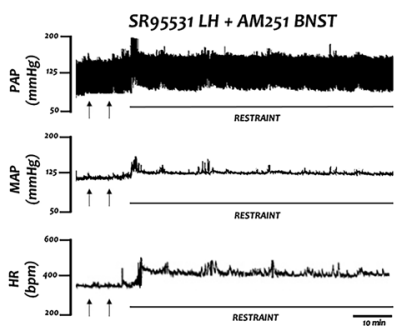

Figure 2. Effect of lateral hypothalamus (LH) treatment with the selective $\mathrm{GABA}_{\mathrm{A}}$ receptor antagonist SR95531 and/or microinjection of the $\mathrm{CB}_{1}$ receptor antagonist AM251 into the bed nucleus of the stria terminalis (BNST) in arterial pressure and heart rate (HR) changes evoked by an acute session of restraint stress. (Top, left) Time-course curves of changes on mean arterial pressure $(\triangle \mathrm{MAP})$ and $H R(\Delta \mathrm{HR})$ evoked by acute restraint stress in animals treated bilaterally into the $\mathrm{LH}$ with saline $(\mathrm{SAL}, 100 \mathrm{~nL})$ or the selective $\mathrm{GABA}_{\mathrm{A}}$ receptor antagonist SR95531 (1 pmol/100 nL), followed by a second microinjection into the BNST of vehicle [solution of saline containing $30 \%$ of DMSO (DMSO), $100 \mathrm{~nL}$ ] or the selective $\mathrm{CB}_{1}$ receptor antagonist AM251 (AM251, $100 \mathrm{pmol} / 100 \mathrm{~nL})$. Circles represent the mean \pm SEM. ${ }^{*} \mathrm{P}<0.05$ over the entire restraint period compared to SAL LH + DMSO BNST group. Two-way ANOVA accompanied by Bonferroni post-hoc test ( $\mathrm{n}=7$ /group). (Top, right) Mean $\triangle \mathrm{MAP}$ and $\Delta \mathrm{HR}$ during the entire restraint stress period in animals treated bilaterally into the LH with SAL $(100 \mathrm{~nL})$ or SR95531 $(1 \mathrm{pmol} / 100 \mathrm{~nL})$, followed by a second microinjection into the BNST of DMSO $(100 \mathrm{~nL})$ or AM251 $(100 \mathrm{pmol} / 100 \mathrm{~nL})$. Columns represent the mean and bars the $\mathrm{SEM} .{ }^{*} \mathrm{P}<0.05 \mathrm{in}$ relation to SAL LH + DMSO BNST group. One-way ANOVA accompanied by Bonferroni post-hoc test $(\mathrm{n}=7 /$ group). (Bottom) Pulsatile arterial pressure (PAP), MAP and HR recordings before and during restraint stress of representative rats illustrating the effect of local $\mathrm{LH}$ treatment with saline (SAL) or the selective GABA receptor antagonist SR95531, followed by a second microinjection into the BNST of vehicle (DMSO) or the selective $\mathrm{CB}_{1}$ receptor antagonist AM251 (AM251). The arrows indicate the microinjection into the $\mathrm{LH}$ and BNST, respectively. Note the increase in restraint-evoked tachycardia in SAL LH + AM251 BNST group, which was inhibited when the $\mathrm{LH}$ was pretreated with the $\mathrm{GABA}_{\mathrm{A}}$ receptor antagonist (SR95531 LH+AM251 BNST group).

and during restraint stress in animals that received vehicle or the selective $\mathrm{GABA}_{\mathrm{A}}$ receptor antagonist into the $\mathrm{LH}$, followed by microinjection of vehicle or the $\mathrm{CB}_{1}$ receptor antagonist into the BNST.

\section{Discussion}

The present results indicate for the first the $\mathrm{LH}$ as part of the neural pathway regulating physiological responses during stressful events by the BNST. In fact, we observed that BNST treatment with the selective $\mathrm{CB}_{1}$ receptor antagonist AM251 into the BNST facilitated the tachycardia evoked by restraint stress, but without affecting the pressor and sympathetically-mediated cutaneous vasoconstriction. The facilitatory influence of $\mathrm{CB}_{1}$ receptor antagonism within the BNST on restraint-evoked tachycardia was completely inhibited in animals pretreated in the $\mathrm{LH}$ with the selective $\mathrm{GABA}_{\mathrm{A}}$ receptor antagonist SR95531. Besides, we identified that bilateral microinjection of AM251 into the BNST decreased the number of Fos-immunoreactive cells in the LH of animals subjected to restraint stress. 

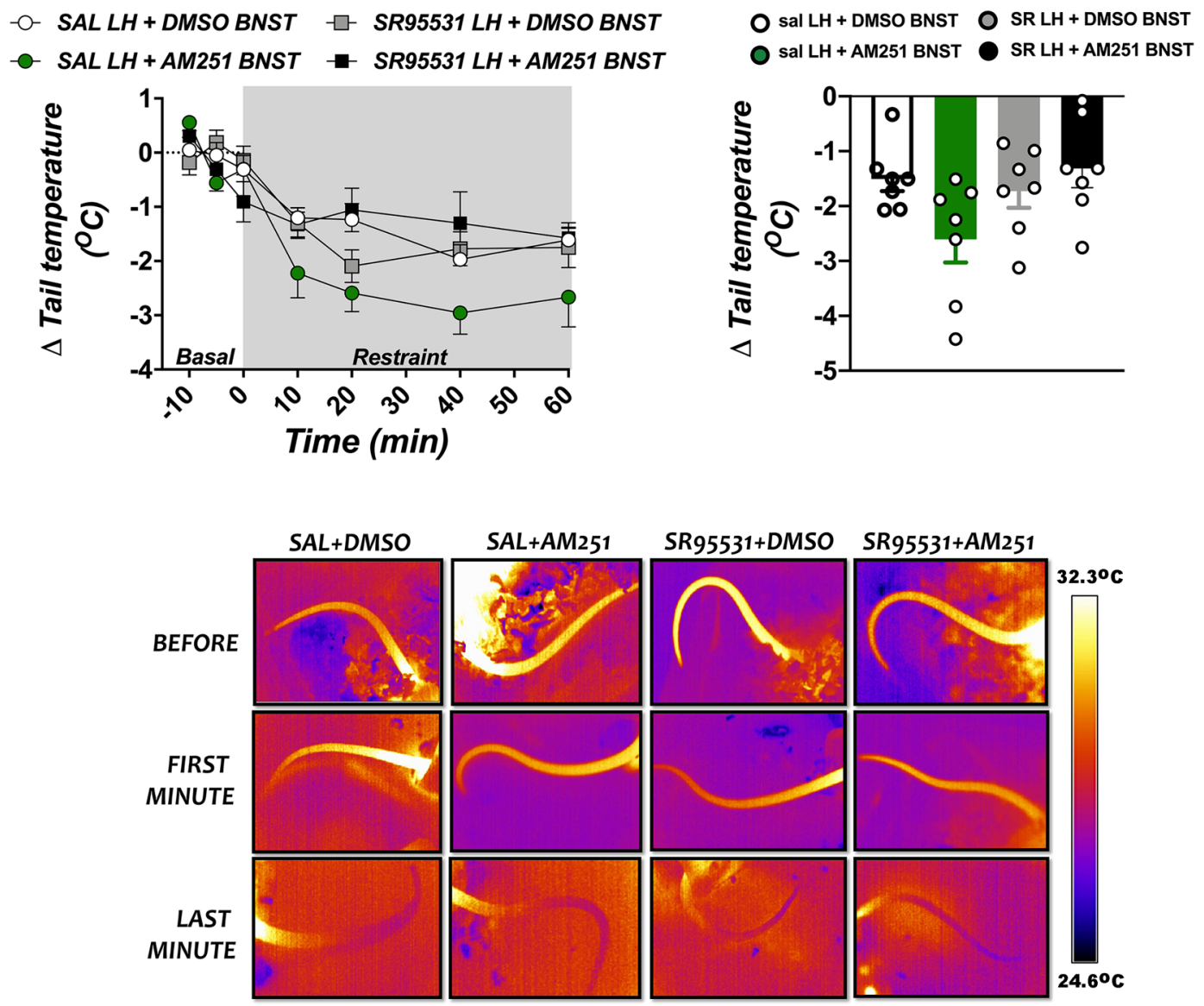

Figure 3. Effect of lateral hypothalamus (LH) treatment with the selective $\mathrm{GABA}_{\mathrm{A}}$ receptor antagonist SR95531 and/or microinjection of the $\mathrm{CB}_{1}$ receptor antagonist AM251 into the bed nucleus of the stria terminalis (BNST) in drop in tail skin temperature evoked by an acute session of restraint stress. (Top, left) Time-course curves of changes in tail skin temperature ( $\Delta$ tail temperature) evoked by acute restraint stress in animals treated bilaterally into the $\mathrm{LH}$ with saline $\left(\mathrm{SAL}, 100 \mathrm{~nL}\right.$ ) or the selective $\mathrm{GABA}_{\mathrm{A}}$ receptor antagonist SR95531 $(1 \mathrm{pmol} / 100 \mathrm{~nL})$, followed by a second microinjection into the BNST of vehicle [solution of saline containing $30 \%$ of DMSO (DMSO), $100 \mathrm{~nL}$ ] or the selective $\mathrm{CB}_{1}$ receptor antagonist AM251 (AM251, $100 \mathrm{pmol} / 100 \mathrm{~nL}$ ). Circles represent the mean \pm SEM. Two-way ANOVA $(\mathrm{n}=7$ /group). (Top, right) Mean $\Delta$ tail temperature during the entire restraint stress period in animals treated bilaterally into the LH with SAL (100 nL) or SR95531 (1 pmol/100 nL), followed by a second microinjection into the BNST of DMSO (100 nL) or AM251 $(100 \mathrm{pmol} / 100 \mathrm{~nL})$. Columns represent the mean and bars the SEM. One-way ANOVA ( $\mathrm{n}=7 /$ group). (Bottom) Images of representative rats showing the tail skin temperature before and at first and last minute of restraint stress in animals treated with saline (SAL) or the selective GABAA receptor antagonist SR95531 into the $\mathrm{LH}$, followed by a second microinjection of vehicle (DMSO) or the selective $\mathrm{CB}_{1}$ receptor antagonist AM251 (AM251) into the BNST. Note the absence of effect of the pharmacological treatments.

We reported previously that microinjection of the selective $\mathrm{CB}_{1}$ receptor antagonist AM251 into the BNST dose-dependently enhanced the tachycardia (without affecting blood pressure and tail skin temperature responses) observed during acute restraint stress ${ }^{13}$. Conversely, increase in either anandamide or 2-arachidonoylglycerol levels in the BNST decreased HR response to restraint stress, and the effect of both endocannabinoids were inhibited in animals pretreated in the BNST with AM251 ${ }^{13}$. These previous results support the present findings indicating an inhibitory role of $\mathrm{CB}_{1}$ receptors in restraint-evoked tachycardia.

$\mathrm{CB}_{1}$ receptors are expressed predominantly in presynaptic terminals ${ }^{36-38}$. Accordingly, $\mathrm{CB}_{1}$ receptor was identified in both excitatory and inhibitory terminals onto BNST neurons, and its activation inhibited local glutamatergic and GABAergic inputs ${ }^{14,15}$. However, $\mathrm{CB}_{1}$ receptor activation present in glutamatergic terminals seem to be prominent during aversive threats within the BNST. For instance, previous findings identified that $\mathrm{CB}_{1}$ receptor blockade enhanced stress-evoked c-fos mRNA in the BNST ${ }^{16,17}$. Besides, we reported recently that the facilitated tachycardia to restraint stress following BNST treatment with AM251 was inhibited by local NMDA glutamate receptor antagonism within the $\mathrm{BNST}^{35}$. The idea that control of cardiovascular responses to restraint by $\mathrm{BNST} \mathrm{CB}_{1}$ receptor is mediated by interaction with local glutamatergic neurotransmission is further supported by evidence that BNST NMDA glutamate receptor plays a facilitatory influence in restraint-evoked HR response without affecting pressor and tail skin temperature changes ${ }^{39,40}$. 


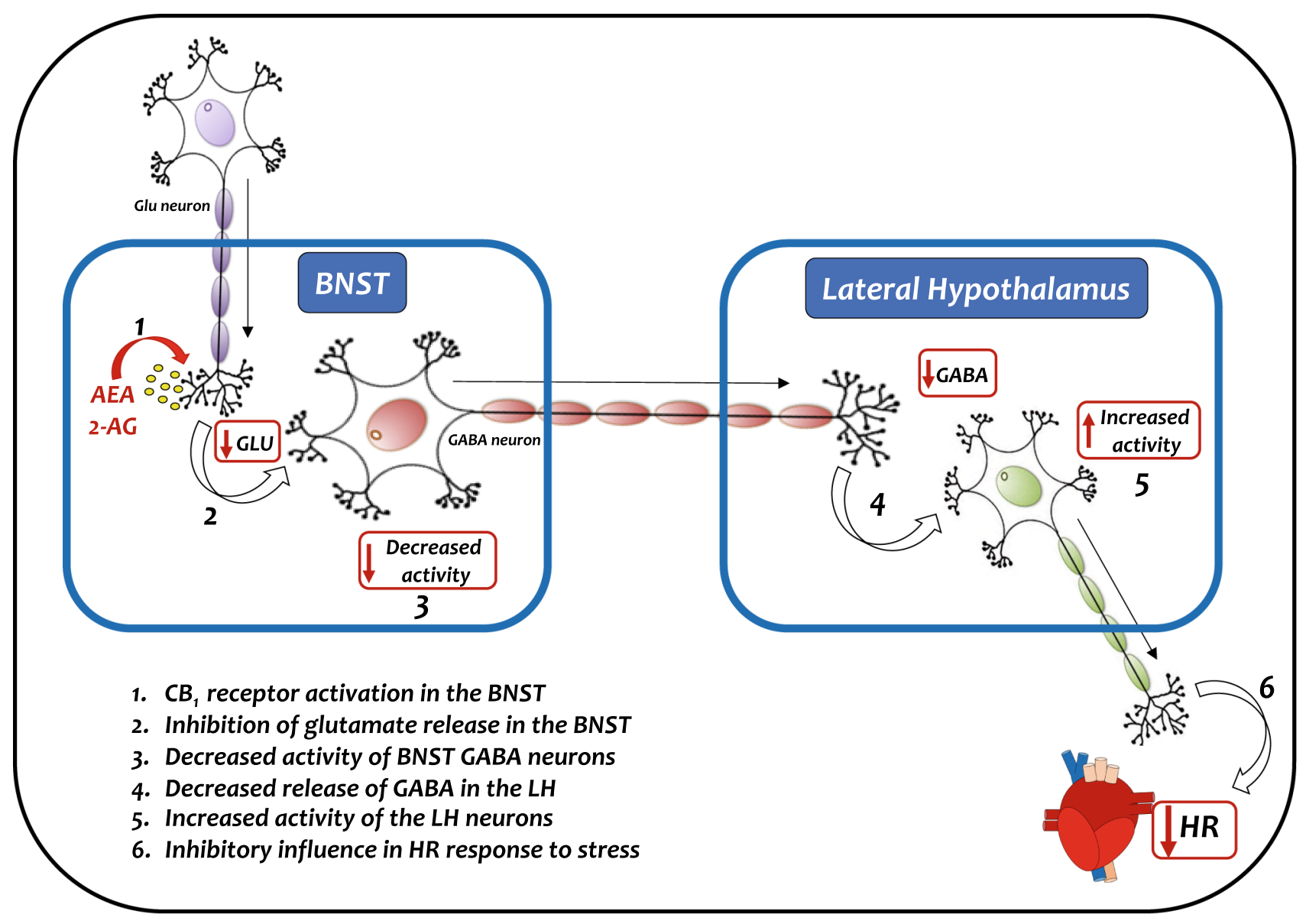

Figure 4. Schematic representation illustrating the proposed mechanism of interaction between BNST endocannabinoid neurotransmission acting via local $\mathrm{CB}_{1}$ receptor and $\mathrm{GABAergic}$ neurotransmission within the $\mathrm{LH}$ in the control of tachycardiac response during aversive threats. Activation of $\mathrm{CB}_{1}$ receptor in the BNST present in glutamatergic terminals (1) inhibits the local release of glutamate (2), which in turn decreases the activity of BNST GABA neurons (3) and, consequently, the release of GABA in the HL (4). The decreased GABA release increase activity of local HL neurons (5), which cause an inhibitory influence in HR increase during stresstul events (6) (please, see the text for details). 2-AG 2-arachidonoylglycerol, AEA anandamide, BNST bed nucleus of the stria terminalis. Glu glutamate, $H R$ heart rate.

Current data provide evidence regarding the neural circuit related to the control of tachycardia to restraint stress by BNST $\mathrm{CB}_{1}$ receptor by indicating a prominent role of projections to the $\mathrm{LH}$. As stated in the Introduction, previous studies provided evidence of GABAergic inputs within the $\mathrm{LH}$ arising from the $\mathrm{BNST}^{33,34}$. These neuroanatomical evidence, taken together with results mentioned above that $\mathrm{CB}_{1}$ receptor activation during aversive threats acts mainly inhibiting glutamatergic terminals during aversive threats ${ }^{16,17,35}$ indicate that the decrease in number of Fos-immunoreactive cells in the LH observed in the present study in animals treated with the $\mathrm{CB}_{1}$ receptor antagonist in the BNST might be the resulted of an increased local glutamatergic neurotransmission, which in turn increase activation of BNST GABAergic neurons projecting to the LH. The hypothesis that GABAergic connection with the $\mathrm{LH}$ mediates the inhibitory control of $\mathrm{BNST} \mathrm{CB}_{1}$ receptor was further supported by demonstration that $\mathrm{LH}$ pretreatment with the $\mathrm{GABA}_{\mathrm{A}}$ receptor antagonist SR95531 completely inhibited the facilitation of $\mathrm{HR}$ increase to restraint stress caused by BNST treatment with the $\mathrm{CB}_{1}$ receptor antagonist AM251. Therefore, the amplitude of the tachycardia evoked by acute stress exposure rely on $\mathrm{CB}_{1}$ receptor within the BNST governing reduction in GABAergic influence exerted by BNST upon LH neurons, which in turn increase activity of LH neurons inhibiting heartbeat during stressful event. This idea is in line with recent report that $\mathrm{GABA}_{\mathrm{A}}$ receptor antagonism within the $\mathrm{LH}$ decreased restraint-evoked tachycardia ${ }^{28}$. Besides, a previous study documented that inhibition of BNST GABAergic terminals within the LH caused increase in local postsynaptic neuronal activity ${ }^{34}$. Figure 4 shows schematic representation illustrating the proposed mechanism involving BNST endocannabinoid neurotransmission and LH GABAergic mechanism for the control of HR response during stressful events.

GABAergic projections from the BNST to the LH have been previously implicated in behavioral responses, including feeding and anxiety-like behavior ${ }^{34,41}$. However, this pathway seem not to be related to the control of cocaine conditioned place preference by LH orexin neurons ${ }^{42}$. Besides, the decrease in anxiety-like behaviors evoked by stimulation of BNST-LH projection was not followed by changes in respiratory rate, which indicated that this neural network was not involved in physiological changes related to this behavioral response $\mathrm{e}^{41}$. 
Therefore, to the best of our knowledge, our findings are the first to indicate an involvement of the BNST-LH pathway in physiological responses during aversive threats ${ }^{7,43}$. Besides, in addition to provide evidence of the brain network involved in the control of cardiovascular responses by BNST endocannabinoid neurotransmission, results reported here also indicate a mechanism involved in neuronal activation within the LH during aversive threats.

GABAergic projections from the BSNT targets glutamatergic neurons within the $\mathrm{LH}^{34}$. Previous studies identified inputs from the $\mathrm{LH}$ in parasympathetic brainstem nuclei ${ }^{44,45}$. Indeed, Deolindo et al ${ }^{27}$ reported that cardiac parasympathetic activity governs the inhibitory control of restraint-evoked HR increase by the LH. Control of tachycardia to restraint by the BNST was also documented to be mediated by facilitation of parasympathetic nervous system ${ }^{5}$. Based on these pieces of evidence, it is possible that the inhibitory control of restraint-evoked HR increase by BNST $\mathrm{CB}_{1}$ receptor occouring via inhibition of GABAergic inputs within the $\mathrm{LH}$ is mediated by an increase in activity of LH glutamatergic neurons projecting to parasympathetic centers in the medulla. However, BNST projections also target neurons expressing orexin and melanin concentrating hormone $(\mathrm{MCH})$ within the $\mathrm{LH}^{7,20}$. Although evidence that BNST GABAergic neurons inhibits $\mathrm{MCH}$ cells within the $\mathrm{LH}^{20}$, these neurons are inhibited by aversive stimuli ${ }^{20}$, which preclude the idea of a role of $\mathrm{MCH}$ cells in control of stress responses by BNST $\mathrm{CB}_{1}$ receptors. Orexin neurons also seem not to be part of the pathway proposed in the present study once this neurochemical mechanism in the brain plays a facilitatory influence in stress-evoked cardiovascular changes ${ }^{46-48}$, so that increased activity of LH orexin neurons would increase rather than decrease restraint-evoked $\mathrm{HR}$ increase. The absence of an involvement of orexin neurons is further supported by evidence that orexinergic mechanisms are not involved in cardiovascular changes caused by restraint ${ }^{47}$.

The idea that control of tachycardia to stress by $\mathrm{BNST} \mathrm{CB}_{1}$ receptors is mediated by direct GABAergic projections to the LH is supported by evidence of the BNST as a prominent source of GABAergic inputs in the $\mathrm{LH}^{20,33}$. Besides, previous studies have indicated that optogenetic activation of BNST GABAergic terminals within the $\mathrm{LH}$ affected feeding and anxiety-like behaviors ${ }^{34,41}$. However, we cannot exclude the possibility that involvement of LH GABAergic neurotransmission in $\mathrm{BNST} \mathrm{CB}_{1}$ receptor control of tachycardia to restraint stress is mediated by recruitment of intermediate brain regions. In fact, previous studies identified LH-projecting GABAergic neurons in brain regions that receive BNST inputs ${ }^{49-52}$ and are involved in control of stress-evoked cardiovascular responses $^{53-55}$, such as amygdala and lateral preoptic area. Therefore, further studies are necessary to directly assess if control of cardiovascular responses to stress by $\mathrm{BNST} \mathrm{CB}_{1}$ receptors are mediated by direct or indirect connections with the LH.

In summary, the results reported in the present study provide evidence of the $\mathrm{LH}$ as part of the neural network regulating the cardiovascular responses to aversive threats by BNST endocannabinoid neurotransmission. In fact, our data indicate that the inhibitory control related to $\mathrm{CB}_{1}$ receptors activation within the BNST in tachycardia to stress is mediated by LH GABAergic neurotransmission acting via local GABA $\mathrm{A}_{\mathrm{A}}$ receptors. Findings reported here also provide evidence that BNST endocannabinoid neurotransmission is potentially involved in activation of LH neurons during aversive threats.

\section{Methods}

Animals. Forty-seven male Wistar rats weighting 240-260 g (60-days-old) were used. Animals were obtained from the animal breeding facility of the São Paulo State University (UNESP) (Botucatu, SP, Brazil), and were housed according to conditions stablished in our laboratory ${ }^{13,28,56,57}$. Briefly, the rats were housed in plastic cages in a temperature-controlled room at $24^{\circ} \mathrm{C}$ in the Animal Facility of the Laboratory of Pharmacology (School of Pharmaceutical Sciences/UNESP). They were kept under a 12:12 h light-dark cycle (lights on between 7:00 am and 7:00 pm) with free access to water and standard laboratory food. Housing conditions and experimental procedures were approved by the Ethical Committee for Use of Animals of the School of Pharmaceutical Sciences/UNESP (approval \# 61/2015), which complies with Brazilian and international guidelines for animal use and welfare. The study was carried out in compliance with the ARRIVE guidelines.

Implant of brain cannulas. Five days before the trial, rats were anesthetized with tribromoethanol $(250 \mathrm{mg} / \mathrm{kg}$, i.p.). After scalp anesthesia with $2 \%$ lidocaine, the skull was exposed and stainless-steel guide cannulas (26 G, $12 \mathrm{~mm}$-long) directed to the LH and/or BNST were bilaterally implanted at a position $1 \mathrm{~mm}$ above the site of injection, using a stereotaxic apparatus (Stoelting, Wood Dale, IL, USA). Stereotaxic coordinates for cannula implantation into the BNST were: antero-posterior $=+7.8 \mathrm{~mm}$ from interaural line; lateral $=4 \mathrm{~mm}$ from the medial suture; dorso-ventral $=-5.8 \mathrm{~mm}$ from the skull, with a lateral inclination of $23^{\circ 58}$. For the $\mathrm{LH}$, the stereotaxic coordinates were: antero-posterior $=+6.2 \mathrm{~mm}$ from interaural line; lateral $=1.8 \mathrm{~mm}$ from the medial suture; dorso-ventral $=-7.6 \mathrm{~mm}$ from the skull; without lateral angulation ${ }^{58}$. Cannulas were fixed to the skull with dental cement and one metal screw. After the surgery, all animals received a poly-antibiotic solution containing streptomycins and penicillins $(560 \mathrm{mg} / \mathrm{ml} / \mathrm{kg}$, i.m.) to prevent infection and the non-steroidal antiinflammatory flunixin meglumine $(0.5 \mathrm{mg} / \mathrm{ml} / \mathrm{kg}$, s.c.) for post-operation analgesia.

Cannulation of femoral artery. One day before the trial, rats were anesthetized with tribromoethanol $(250 \mathrm{mg} / \mathrm{kg}$, i.p.), and a catheter (Clay Adams, Parsippany, NJ, USA) filled with a solution of heparin (50UI/ml, Hepamax-S, Blausiegel, Cotia, SP, Brazil) diluted in saline $(0.9 \% \mathrm{NaCl})$ was inserted into the abdominal aorta through the femoral artery for cardiovascular recording, according to procedures previously described by our group $^{13,57,59,60}$. After the surgery, the non-steroidal anti-inflammatory flunixin meglumine $(0.5 \mathrm{mg} / \mathrm{ml} / \mathrm{kg}$, s.c.) was administered for post-operation analgesia. The animals were kept in individual cages during the postoperative period and cardiovascular recording. 
Restraint stress. The acute restraint stress consisted of introducing the animals into plastic cylindrical tubes (diameter $=6.5 \mathrm{~cm}$, length $=15 \mathrm{~cm}$ ), which were ventilated by $1 / 2$ inch holes that comprised approximately $20 \%$ of the tube, as previously described by us ${ }^{5,13}$. The animals were maintained for a period of 60 min into the restraint tube $e^{5,13,27}$. Each animal was submitted to only one session of stress in order to avoid habituation ${ }^{61-63}$.

Blood pressure and heart rate recording. The catheter implanted into the femoral artery was connected to a pressure transducer (DPT100, Utah Medical Products Inc., Midvale, UT, USA), and pulsatile arterial pressure (PAP) was recorded using an amplifier (Bridge Amp, ML224, ADInstruments, Australia) and an acquisition board (PowerLab 4/30, ML866/P, ADInstruments, NSW, Australia) connected to a personal computer, as previously described by $\mathrm{us}^{13,57,64,65}$. Mean arterial pressure (MAP) and HR values were derived from the PAP recording.

Tail cutaneous temperature measurement. Vasomotor sympathetic activity activation during aversive threats decreases cutaneous blood flow ${ }^{66}$ that in turn reduces cutaneous temperature ${ }^{67}$. Therefore, the drop in tail cutaneous temperature was evaluated as an indirect measurement of vasomotor sympathetic response in cutaneous beds during restraint stress ${ }^{13,35,67}$.

The tail cutaneous temperature was recorded using a thermal camera (IRI4010, Infra Red Integrated Systems Ltd., Northampton, UK). The analysis was performed using a software for thermographic analysis, and temperature was represented by color intensity variations $s^{67,68}$. For image analysis, the temperature was measured on five points along the animal's tail, and the mean value was calculated for each recording $13,35,39,69$.

Drug microinjection. The needles (33G, Small Parts, Miami Lakes, FL, USA) used for microinjection into the BNST and/or LH were $1 \mathrm{~mm}$ longer than the guide cannulas and were connected to a $2 \mu \mathrm{L}$ syringe $(7002-\mathrm{KH}$, Hamilton Co., Reno, NV, USA) via a PE-10 tubing (Clay Adams, Parsippany, NJ, USA). Intra-cerebral microinjections were performed within a $5 \mathrm{~s}$ period, and the needle was left in the guide cannula for $1 \mathrm{~min}$ after the microinjection before being removed. Microinjection was performed without restraining the animals, and drugs were administrated into the LH and BNST in a final volume of $100 \mathrm{~nL}$ per side $\mathrm{e}^{5,13,27,28,67}$.

Drugs and solutions. SR95531 (selective GABA A $_{\mathrm{A}}$ receptor antagonist) (TOCRIS, West-woods Business Park, Ellisville, MO, USA; cat. \#1262), 2,2,2-tribromoethanol (Sigma-Aldrich, St Louis, Missouri, USA; cat. \#T48402) and urethane (Sigma-Aldrich; cat. \#U2500) were dissolved in saline (NaCl 0.9\%). AM251 (N-(piperidin-1-yl)-5(4-iodophenyl)-1-(2,4-dichlo-rophenyl)-4-methyl-1H-pyrazole-3 carboxamide) (selective $\mathrm{CB}_{1}$ receptor antagonist) (TOCRIS, cat. \#1117) was dissolved in a solution of saline containing 30\% of DMSO (DMSO). Flunixin meglumine (Banamine, Schering Plough, Cotia, SP, Brazil) and the polyantibiotic preparation of streptomycins and penicillins (Pentabiotico, Fort Dodge, Campinas, SP, Brazil) were used as provided.

Immunohistochemistry. Thirty minutes after the end of the stress session, the animals were anesthetized with urethane (1.2 g/kg,i.p.) and perfused with saline phosphate (PBS) (1X pH 7.4) accompanied by $4 \%$ paraformaldehyde in solution with phosphate buffer ( $\mathrm{pH}$ 7.4). Then, the brain was removed and post-fixed in paraformaldehyde for $2 \mathrm{~h}$ and transferred to $30 \%$ sucrose solution in PBS at $4{ }^{\circ} \mathrm{C}$. Two days later, the brains were frozen in dry ice powder for $1 \mathrm{~h}$, and then stored in freezer at $-80^{\circ} \mathrm{C}$ until processing.

Before the imunnohistochemistry procedures, the brains were sectioned in a cryostat $\left(-20^{\circ} \mathrm{C}\right)(\mathrm{CM} 1900$, Leica, Germany) with a thickness of $35 \mu \mathrm{m}$ according to coodinates of Paxinos and Watson ${ }^{58}$. The slices containing the LH region were washed 3 times (10 min each wash) in PBS and incubated in blocking solution ( $3 \%$ goat serum and $0.25 \%$ Triton X-100) dissolved in PBS for one hour at room temperature. After the blockage, the slices were incubated with anti- Fos primary antibody (1:2000 dilution; Cell Signaling Technology, Danvers, MA, USA; produced in rabbit) for $24 \mathrm{~h}$ at $4{ }^{\circ} \mathrm{C}$. After the incubation, the slices were washed with PBS 3 times $(10$ min each wash) and incubated with biotinylated anti-rabbit secondary antibody (dilution 1: 600; Vector Laboratories, Burlingame, CA, USA) in PBS-Tx (0.25\% Triton X-100) and $3 \%$ goat serum for $2 \mathrm{~h}$ at room temperature. The slices were then washed with PBS 3 times (10 min each wash) and incubated for $1 \mathrm{~h}$ in avidin-biotin-peroxidase solution (ABC Elite kit, PK-6100; Vector Laboratories, Burlingame, CA, USA), 0.5\% Triton X-100 and PBS. The slices were then washed 3 times (10 min each wash) and incubated in 3,3'-diaminobenzidine (DAB) for seven min. Then, they were washed 4 times ( 5 min each wash), transferred to PBS solution and mounted on gelatinized slides. After drying, the slides were hydrated in distilled water and then gradient dehydrated by increasing ethanol titrations (30\%, 60\%, 90\%, 95\% and 100\%) and xylol (LabSynth, São Paulo, Brazil). Finally, they were covered with Permount (Sigma-Aldrich, St. Louis, MA, USA) and coverslips.

Immunostaining of Fos was captured in a microscope coupled to a camera (Zeiss Axioskop 2). Two images were captured per slice (right and left hemispheres) and at least two slices were obtained per animal, and the counting was performed from a fixed area of the LH. The Fos-positive cells were counted using the ImageJ software (version 1.52q; website: https://imagej.nih.gov/ij/download.html). The results were expressed as mean number of Fos-positive cells $/ \mathrm{mm}^{2}$. The $\mathrm{LH}$ was identified according to the atlas of rat's brain of Paxinos and Watson ${ }^{58}$.

Experimental design. Experimental procedures were as previously described by us ${ }^{13,35,70}$. Briefly, animals were brought to the experimental room in their own cages. Animals were allowed at least 60 min to adapt to the experimental room conditions, such as sound and illumination, before starting the experiments. The experimental room was temperature controlled $\left(24^{\circ} \mathrm{C}\right)$ and acoustically isolated from the other rooms. 

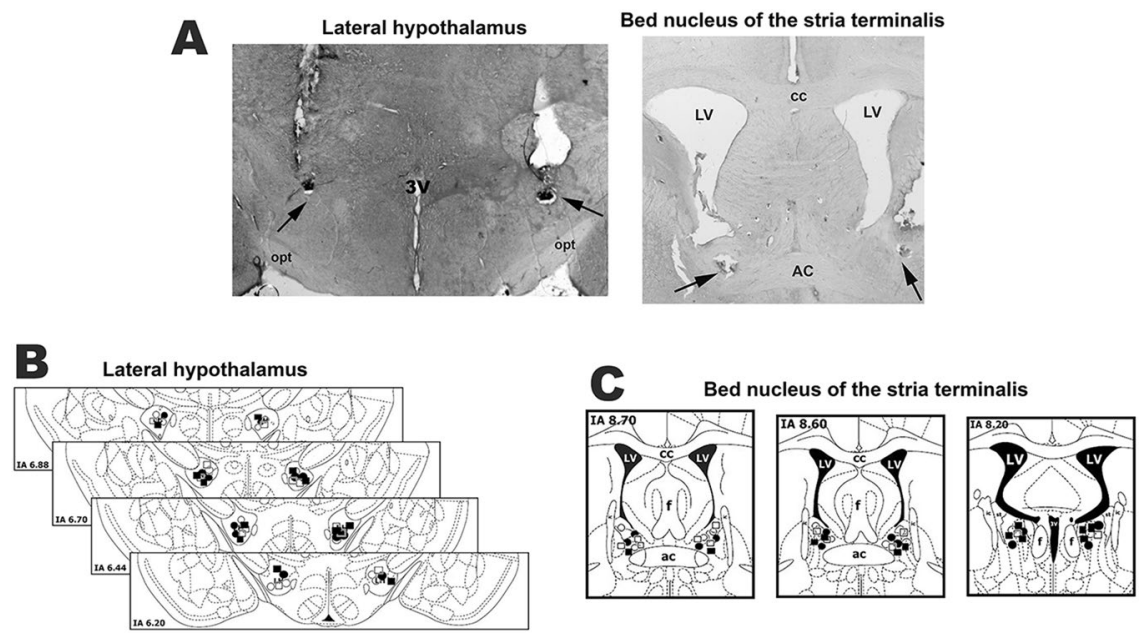

Figure 5. (A) Photomicrographs of coronal brain sections from representative rats showing bilateral sites of microinjection into the lateral hypothalamus (LH) (left) and bed nucleus of the stria terminalis (BNST) (right). (B, C) Diagrammatic representations based on the rat brain atlas of Paxinos and Watson ${ }^{58}$ indicating the microinjection sites into the lateral hypothalamus (B) and BNST (C) of all animals used for evaluation of the involvement of $\mathrm{GABA}_{\mathrm{A}}$ receptor within the $\mathrm{LH}$ in cardiovascular changes evoked by microinjection of the selective $\mathrm{CB}_{1}$ receptor antagonist AM251 into the BNST. White circles: saline LH + DMSO BNST group; black circles: saline LH + AM251 BNST group; white squares: SR95531 LH + DMSO BNST group; black squares: SR95531 LH + AM251 BNST group. $3 V$ third ventricle, $a c$ anterior commissure, $c c$ corpus callosum, $f$ fornix, $I A$ interaural coordinate, ic internal capsule, $L V$ lateral ventricle, opt optic chiasm, st stria terminalis.

Effect of $C B_{1}$ receptor blockade within the BNST on number of Fos-positive neurons in the LH of stressed animals. This protocol aimed to test the hypothesis that antagonism of $\mathrm{CB}_{1}$ receptor within the BNST decreases the number of Fos-positive neurons in the $\mathrm{LH}$ during restraint stress. For this, animals were treated with either vehicle (saline containing $30 \%$ of DMSO, $100 \mathrm{~nL} /$ side, $n=8$ ) or the selective $\mathrm{CB}_{1}$ receptor antagonist $\mathrm{AM} 251$ $(100 \mathrm{pmol} / 100 \mathrm{~nL} / \mathrm{side}, \mathrm{n}=11)$ into the $\mathrm{BNST}^{13,35}$. Ten min after the treatment, all rats were submitted to a 60 min session of restraint stress. Thirty minutes after the end of the stress session, the animals were anesthetized with urethane (1.2 g/kg,i.p.), perfused, and their brains were processed for immunohistochemistry protocol.

Effect $G A B A_{A}$ receptor antagonism in the $L H$ in changes of cardiovascular and tail skin temperature reactivity to acute restraint stress evoked by $C B_{1}$ receptor blockade in the BNST. The aim of this protocol was to evaluate the involvement $\mathrm{GABAergic}$ neurotransmission in the $\mathrm{LH}$, acting via local $\mathrm{GABA}_{\mathrm{A}}$ receptors, in changes of restraintevoked MAP and HR increase and drop in tail skin temperature caused by $\mathrm{CB}_{1}$ receptor antagonism in the BNST. For this, independent sets of rats were pretreated into the $\mathrm{LH}$ with either the selective $\mathrm{GABA}_{\mathrm{A}}$ receptor antagonist SR95531 $\left(1 \mathrm{pmol} / 100 \mathrm{~nL}\right.$ ) or vehicle (saline, $100 \mathrm{~nL} / \mathrm{side}^{28}{ }^{2}$. Five minutes later, the animals received either vehicle (saline containing 30\% of DMSO, $100 \mathrm{~nL} / \mathrm{side}$ ) or AM251 (100 pmol/100 nL/side) into the BNST $(\mathrm{n}=7 \text { /group, Table } 1)^{13,35}$. Five minutes after the second pharmacological treatment, animals in all experimental groups underwent a 60 min session of restraint stress.

Blood pressure and HR recording started at least $30 \mathrm{~min}$ before the onset of the restraint, and was performed throughout the stress session. The tail skin temperature was measured 10, 5 and 0 min before the restraint for baseline values, and at 10,20, 40 and 60 min during restraint ${ }^{13,35}$. Each animal received a single pharmacological treatment and was submitted to one session of restraint. In each protocol, animals were randomly distributed among the several experimental groups.

Histological determination of the microinjection sites. At the end of each experiment, animals were anesthetized with urethane $(1.2 \mathrm{~g} / \mathrm{kg}$, i.p.), and $1 \%$ Evan's blue dye was microinjected into the brain at the same volume of drug injection (i.e., $100 \mathrm{~nL} /$ side) as a marker of microinjection site. Then, the brains were removed and post-fixed in $10 \%$ formalin solution for at least $48 \mathrm{~h}$ at $4{ }^{\circ} \mathrm{C}$. Afterwards, serial $40 \mu \mathrm{m}$ thick sections of the BNST region were cut using a cryostat (CM1900, Leica, Wetzlar, Germany) for identification of the microinjection sites according to Paxinos and Watson ${ }^{58}$.

Photomicrographs of coronal brain sections depicting bilateral microinjection sites in the LH and BNST of representative animals are presented in Fig. 5. Diagrammatic representations based on the brain atlas of Paxinos and Watson ${ }^{58}$ indicating the microinjection sites into the LH and BNST of all animals used in the present study are also presented in Fig. 5.

Data analysis. Data were expressed as mean \pm SEM. The number of Fos-positive cells in the LH were compared using the Student's t-test. The basal values of MAP, HR and tail skin temperature were compared using oneway ANOVA followed by Bonferroni's post-hoc test. Restraint-evoked cardiovascular changes were obtained by 
calculating the difference between the values recorded during the restraint stress and the baseline value obtained by the mean of points recorded across the $10 \mathrm{~min}$ before the restraint onset. The time-course curves of MAP, $\mathrm{HR}$ and tail skin temperature changes were analyzed using two-way ANOVA, with treatment as main factor and time as repeated measurement, followed the by the Bonferroni's post-hoc test. The mean of the values during the entire restraint session was also calculated, and these values were compared using one-way ANOVA followed by Bonferroni's post-hoc test. Results of statistical tests with $\mathrm{P}<0.05$ were considered significant.

\section{Data availability}

Data available on request from the authors.

Received: 13 May 2021; Accepted: 26 July 2021

Published online: 09 August 2021

\section{References}

1. Crestani, C. et al. Mechanisms in the bed nucleus of the stria terminalis involved in control of autonomic and neuroendocrine functions: A review. Curr. Neuropharmacol. 11, 141-159 (2013).

2. Myers, B. Corticolimbic regulation of cardiovascular responses to stress. Physiol. Behav. 172, 49-59 (2017).

3. Radley, J. J. \& Johnson, S. B. Anteroventral bed nuclei of the stria terminalis neurocircuitry: Towards an integration of HPA axis modulation with coping behaviors-Curt Richter Award Paper 2017. Psychoneuroendocrinology 89, 239-249 (2018).

4. Resstel, L. B. M. et al. Anxiolytic-like effects induced by acute reversible inactivation of the bed nucleus of stria terminalis. Neuroscience 154, 869-876 (2008).

5. Crestani, C. C., Alves, F. H. F., Tavares, R. F. \& Corrêa, F. M. A. Role of the bed nucleus of the stria terminalis in the cardiovascular responses to acute restraint stress in rats. Stress 12, 268-278 (2009).

6. Crestani, C. C., Alves, F. H. F., Resstel, L. B. M. \& Correa, F. M. A. The bed nucleus of the stria terminalis modulates exercise-evoked cardiovascular responses in rats. Exp. Physiol. https://doi.org/10.1113/expphysiol.2009.049056 (2010).

7. Ch'ng, S., Fu, J., Brown, R. M., McDougall, S. J. \& Lawrence, A. J. The intersection of stress and reward: BNST modulation of aversive and appetitive states. Prog. Neuro-Psychopharmacol. Biol. Psychiatry 87, 108-125 (2018).

8. Bedse, G., Centanni, S. W., Winder, D. G. \& Patel, S. Endocannabinoid signaling in the central amygdala and bed nucleus of the stria terminalis: Implications for the pathophysiology and treatment of alcohol use disorder. Alcohol. Clin. Exp. Res. 43, 2014-2027 (2019).

9. Matsuda, L. A., Bonner, T. I. \& Lolait, S. J. Localization of cannabinoid receptor mRNA in rat brain. J. Comp. Neurol. 327, 535-550 (1993).

10. Tsou, K., Brown, S., Sañudo-Peña, M. C., Mackie, K. \& Walker, J. M. Immunohistochemical distribution of cannabinoid CB1 receptors in the rat central nervous system. Neuroscience 83, 393-411 (1998).

11. Gomes-de-Souza, L. et al. CB1 and CB2 receptors in the bed nucleus of the stria terminalis differently modulate anxiety-like behaviors in rats. Prog. Neuro-Psychopharmacology Biol. Psychiatry 110, 110284 (2021).

12. Gulyas, A. I. et al. Segregation of two endocannabinoid-hydrolyzing enzymes into pre- and postsynaptic compartments in the rat hippocampus, cerebellum and amygdala. Eur. J. Neurosci. 20, 441-458 (2004).

13. Gomes-de-Souza, L. et al. Involvement of endocannabinoid neurotransmission in the bed nucleus of stria terminalis in cardiovascular responses to acute restraint stress in rats. Br. J. Pharmacol. 173, 2833-2844 (2016).

14. Puente, N. et al. Localization and function of the cannabinoid CB1 receptor in the anterolateral bed nucleus of the stria terminalis. PLoS ONE 5, e8869 (2010).

15. Puente, N. et al. Polymodal activation of the endocannabinoid system in the extended amygdala. Nat. Neurosci. 14, 1542-1547 (2011).

16. Newsom, R. J. et al. Cannabinoid receptor type 1 antagonism significantly modulates basal and loud noise induced neural and hypothalamic-pituitary-adrenal axis responses in male Sprague-Dawley rats. Neuroscience 204, 64-73 (2012).

17. Newsom, R. J. et al. Remote CB1 receptor antagonist administration reveals multiple sites of tonic and phasic endocannabinoid neuroendocrine regulation. Psychoneuroendocrinology 113, 104549 (2020).

18. Lange, M. D. et al. Cannabinoid CB1 receptors in distinct circuits of the extended amygdala determine fear responsiveness to unpredictable threat. Mol. Psychiatry 22, 1422-1430 (2017).

19. Hosoya, Y. \& Matsushita, M. Cells of origin of the descending afferents to the lateral hypothalamic area in the rat, studied with the horseradish peroxidase method. Neurosci. Lett. 18, 231-236 (1980).

20. González, J. A., Iordanidou, P., Strom, M., Adamantidis, A. \& Burdakov, D. Awake dynamics and brain-wide direct inputs of hypothalamic MCH and orexin networks. Nat. Commun. 7, 11395 (2016).

21. Mu, M.-D. et al. A limbic circuitry involved in emotional stress-induced grooming. Nat. Commun. 11, 2261 (2020).

22. Carrive, P. Orexin, stress and central cardiovascular control: A link with hypertension?. Neurosci. Biobehav. Rev. 74, 376-392 (2017).

23. Soya, S. \& Sakurai, T. Orexin as a modulator of fear-related behavior: Hypothalamic control of noradrenaline circuit. Brain Res. 1731, $146037(2020)$

24. Johnson, P. L., Molosh, A., Fitz, S. D., Truitt, W. A. \& Shekhar, A. Orexin, stress, and anxiety/panic states. Prog. Brain Res. 198, 133-161 (2012).

25. Iwata, J., LeDoux, J. E. \& Reis, D. J. Destruction of intrinsic neurons in the lateral hypothalamus disrupts the classical conditioning of autonomic but not behavioral emotional responses in the rat. Brain Res. 368, 161-166 (1986).

26. LeDoux, J. E., Iwata, J., Cicchetti, P. \& Reis, D. J. Different projections of the central amygdaloid nucleus mediate autonomic and behavioral correlates of conditioned fear. J. Neurosci. https://doi.org/10.1523/jneurosci.1001-06.2006 (1988).

27. Deolindo, M. V. et al. NMDA receptors in the lateral hypothalamus have an inhibitory influence on the tachycardiac response to acute restraint stress in rats. Eur. J. Neurosci. 38, 2374-2381 (2013).

28. Gomes-de-Souza, L., Benini, R., Costa-Ferreira, W. \& Crestani, C. C. GABAA but not GABAB receptors in the lateral hypothalamus modulate the tachycardic response to emotional stress in rats. Eur. Neuropsychopharmacol. 29, 672-680 (2019).

29. Cullinan, W. E., Herman, J. P. \& Watson, S. J. Ventral subicular interaction with the hypothalamic paraventricular nucleus: evidence for a relay in the bed nucleus of the stria terminalis. J. Comp. Neurol. 332, 1-20 (1993).

30. Radley, J. J., Gosselink, K. L. \& Sawchenko, P. E. A discrete GABAergic relay mediates medial prefrontal cortical inhibition of the neuroendocrine stress response. J. Neurosci. 29, 7330-7340 (2009).

31. Kudo, T. et al. Three types of neurochemical projection from the bed nucleus of the stria terminalis to the ventral tegmental area in adult mice. J. Neurosci. 32, 18035-18046 (2012).

32. Poulin, J.-F., Arbour, D., Laforest, S. \& Drolet, G. Neuroanatomical characterization of endogenous opioids in the bed nucleus of the stria terminalis. Prog. Neuro-Psychopharmacol. Biol. Psychiatry 33, 1356-1365 (2009). 
33. Gritti, I., Mainville, L. \& Jones, B. E. Projections of GABAergic and cholinergic basal forebrain and GABAergic preoptic-anterior hypothalamic neurons to the posterior lateral hypothalamus of the rat. J. Comp. Neurol. 339, 251-268 (1994).

34. Jennings, J. H., Rizzi, G., Stamatakis, A. M., Ung, R. L. \& Stuber, G. D. The inhibitory circuit architecture of the lateral hypothalamus orchestrates feeding. Science 341, 1517-1521 (2013).

35. Gomes-de-Souza, L., Costa-Ferreira, W., Oliveira, L. A., Benini, R. \& Crestani, C. C. Cannabinoid receptor type 1 in the bed nucleus of the stria terminalis modulates cardiovascular responses to stress via local $\mathrm{N}$-methyl-D-aspartate receptor/neuronal nitric oxide synthase/soluble guanylate cyclase/protein kinase G signaling. J. Psychopharmacol. 34, 429-440 (2020).

36. Katona, I. \& Freund, T. F. Multiple functions of endocannabinoid signaling in the brain. Annu. Rev. Neurosci. 35, 529-558 (2012).

37. Mechoulam, R. \& Parker, L. A. The endocannabinoid system and the brain. Annu. Rev. Psychol. 64, 21-47 (2013).

38. Araque, A., Castillo, P. E., Manzoni, O. J. \& Tonini, R. Synaptic functions of endocannabinoid signaling in health and disease. Neuropharmacology 124, 13-24 (2017).

39. Adami, M. B., Barretto-De-Souza, L., Duarte, J. O., Almeida, J. \& Crestani, C. C. Both N-methyl-D-aspartate and non-N-methyl$\mathrm{D}$-aspartate glutamate receptors in the bed nucleus of the stria terminalis modulate the cardiovascular responses to acute restraint stress in rats. J. Psychopharmacol. 31, 674-681 (2017).

40. Barretto-de-Souza, L., Adami, M. B., Benini, R. \& Crestani, C. C. Dual role of nitrergic neurotransmission in the bed nucleus of the stria terminalis in controlling cardiovascular responses to emotional stress in rats. Br. J. Pharmacol. 175, 3773-3783 (2018).

41. Kim, S.-Y. et al. Diverging neural pathways assemble a behavioural state from separable features in anxiety. Nature 496, 219-223 (2013)

42. Sartor, G. C. \& Aston-Jones, G. Regulation of the ventral tegmental area by the bed nucleus of the stria terminalis is required for expression of cocaine preference. Eur. J. Neurosci. 36, 3549-3558 (2012).

43. Kim, S.-R. \& Kim, S.-Y. Functional dissection of glutamatergic and GABAergic neurons in the bed nucleus of the stria terminalis. Mol. Cells https://doi.org/10.14348/molcells.2021.0006 (2021).

44. Luiten, P. G. M., ter Horst, G. J. \& Steffens, A. B. The hypothalamus, intrinsic connections and outflow pathways to the endocrine system in relation to the control of feeding and metabolism. Prog. Neurobiol. 28, 1-54 (1987).

45. ter Horst, G. J., Luiten, P. G. M. \& Kuipers, F. Descending pathways from hypothalamus to dorsal motor vagus and ambiguus nuclei in the rat. J. Auton. Nerv. Syst. 11, 59-75 (1984).

46. Beig, M. I., Dampney, B. W. \& Carrive, P. Both Ox1r and Ox2r orexin receptors contribute to the cardiovascular and locomotor components of the novelty stress response in the rat. Neuropharmacology 89, 146-156 (2015).

47. Furlong, T. M., Vianna, D. M. L., Liu, L. \& Carrive, P. Hypocretin/orexin contributes to the expression of some but not all forms of stress and arousal. Eur. J. Neurosci. 30, 1603-1614 (2009).

48. Kayaba, Y. et al. Attenuated defense response and low basal blood pressure in orexin knockout mice. Am. J. Physiol. Integr. Comp. Physiol. 285, R581-R593 (2003).

49. Wayner, M. J., Barone, F. C., Scharoun, S. L., Guevara-Aguilar, R. \& Aguilar-Baturoni, H. U. Limbic connections to the lateral preoptic area: A horseradish peroxidase study in the rat. Neurosci. Biobehav. Rev. 7, 375-384 (1983).

50. Dong, H. W. \& Swanson, L. W. Projections from bed nuclei of the stria terminalis, anteromedial area: Cerebral hemisphere integration of neuroendocrine, autonomic, and behavioral aspects of energy balance. J. Comp. Neurol. 494, 142-178 (2006).

51. Myers, B., Mark Dolgas, C., Kasckow, J., Cullinan, W. E. \& Herman, J. P. Central stress-integrative circuits: Forebrain glutamatergic and GABAergic projections to the dorsomedial hypothalamus, medial preoptic area, and bed nucleus of the stria terminalis. Brain Struct. Funct. 219, 1287-1303 (2014)

52. Liu, J. et al. Differential efferent projections of GABAergic neurons in the basolateral and central nucleus of amygdala in mice. Neurosci. Lett. 745, 10 (2021).

53. Fortaleza, E. A. T., Tavares, R. F. \& Corrêa, F. M. A. The medial amygdaloid nucleus modulates cardiovascular responses to acute restraint in rats. Neuroscience 159, 717-726 (2009).

54. Duarte, J. O., Gomes, K. S., Nunes-de-Souza, R. L. \& Crestani, C. C. Role of the lateral preoptic area in cardiovascular and neuroendocrine responses to acute restraint stress in rats. Physiol. Behav. 175, 16-21 (2017).

55. Sanders, B. J., Wirtz-Nole, C., DeFord, S. M. \& Erling, B. F. Central amygdaloid lesions attenuate cardiovascular responses to acute stress in rats with borderline hypertension. Physiol. Behav. 56, 709-713 (1994).

56. Duarte, J. O., Cruz, F. C., Leão, R. M., Planeta, C. S. \& Crestani, C. C. Stress vulnerability during adolescence. Psychosom. Med. 77, 186-199 (2015).

57. Almeida, J., Duarte, J. O., Oliveira, L. A. \& Crestani, C. C. Effects of nitric oxide synthesis inhibitor or fluoxetine treatment on depression-like state and cardiovascular changes induced by chronic variable stress in rats. Stress 18, 462-474 (2015).

58. Paxinos, G. \& Watson, C. The Rat Brain in Stereotaxic Coordinates 3rd edn. (Academic Press, 1997).

59. Costa-Ferreira, W., Vieira, J. O., Almeida, J., Gomes-de-Souza, L. \& Crestani, C. C. Involvement of type 1 angiontensin II receptor (AT1) in cardiovascular changes induced by chronic emotional stress: Comparison between homotypic and heterotypic stressors. Front. Pharmacol. 7, 262 (2016).

60. Costa-Ferreira, W., Gomes-de-Souza, L. \& Crestani, C. C. Role of angiotensin receptors in the medial amygdaloid nucleus in autonomic, baroreflex and cardiovascular changes evoked by chronic stress in rats. Eur. J. Neurosci. 53, 763-777 (2021).

61. Benini, R., Oliveira, L. A., Gomes-de-Souza, L. \& Crestani, C. C. Habituation of the cardiovascular responses to restraint stress in male rats: Influence of length, frequency and number of aversive sessions. Stress 22, 151-161 (2019).

62. Santos, C. E., Benini, R. \& Crestani, C. C. Spontaneous recovery, time course, and circadian influence on habituation of the cardiovascular responses to repeated restraint stress in rats. Pflügers Arch. Eur. J. Physiol. 472, 1495-1506 (2020).

63. Benini, R., Oliveira, L. A., Gomes-de-Souza, L., Rodrigues, B. \& Crestani, C. C. Habituation of the cardiovascular responses to restraint stress is inhibited by exposure to other stressor stimuli and exercise training. J. Exp. Biol. https://doi.org/10.1242/jeb. $219501(2020)$

64. Almeida, J., Oliveira, L. A., Benini, R. \& Crestani, C. C. Role of hippocampal nitrergic neurotransmission in behavioral and cardiovascular dysfunctions evoked by chronic social stress. Nitric Oxide 94, 114-124 (2020).

65. Costa-Ferreira, W., Gomes-de-Souza, L. \& Crestani, C. C. AT2 and MAS (but not AT1) angiotensinergic receptors in the medial amygdaloid nucleus modulate the baroreflex activity in rats. Pflügers Arch. Eur. J. Physiol. 471, 1173-1182 (2019).

66. Blessing, W. W. Lower brainstem pathways regulating sympathetically mediated changes in cutaneous blood flow. Cell. Mol. Neurobiol. 23, 527-538 (2003).

67. Vianna, D. M. L. \& Carrive, P. Changes in cutaneous and body temperature during and after conditioned fear to context in the rat. Eur. J. Neurosci. 21, 2505-2512 (2005).

68. Busnardo, C. et al. Nitrergic neurotransmission in the paraventricular nucleus of the hypothalamus modulates autonomic, neuroendocrine and behavioral responses to acute restraint stress in rats. Prog. Neuro-Psychopharmacol. Biol. Psychiatry 90, 16-27 (2019).

69. Barretto-de-souza, L., Benini, R., Reis-silva, L. L. \& Crestani, C. C. Corticotropin-releasing factor neurotransmission in the lateral hypothalamus modulates the tachycardiac response during acute emotional stress in rats. Brain Res. Bull. 166, 102-109 (2021).

70. Oliveira, L. A., Gomes-de-Souza, L., Benini, R. \& Crestani, C. C. Control of cardiovascular responses to stress by CRF in the bed nucleus of stria terminalis is mediated by local NMDA/nNOS/sGC/PKG signaling. Psychoneuroendocrinology 89, 168-176 (2018). 


\title{
Acknowledgements
}

This work was supported by grant from FAPESP (Grants \# 2017/19249-0 and 2019/24478-3), CNPq (Grant \# 431339/2018-0) and Scientific Support and Development Program of School of Pharmaceutical Sciences (UNESP). This study was financed in part by the Coordenação de Aperfeiçoamento de Pessoal de Nível Superior-Brasil (CAPES) -Finance Code 001. LGS and WCF were FAPESP PhD fellows (Process \# 2016/05028-9 and 2016/05218-2). MMM is CAPES PhD fellow. CCC and CHX are CNPq research fellows (Process \# 304108/2018-9 and 406393/2018-4, respectively).

\section{Author contributions}

L.G.S.: Conceptualization, Methodology, Formal analysis, Investigation, Writing-Original Draft, Visualization. W.C.F.: Formal analysis, Investigation, Writing-Review \& Editing. M.M.M.: Formal analysis, Investigation, Writing-Review \& Editing. C.H.X.: Formal analysis, Investigation, Resources, Writing-Review \& Editing, Supervision. C.C.C.: Conceptualization, Methodology, Resources, Data Curation, Writing-Review \& Editing, Visualization, Supervision, Project administration, Funding acquisition.

\section{Competing interests}

The authors declare no competing interests.

\section{Additional information \\ Correspondence and requests for materials should be addressed to C.C.C.}

Reprints and permissions information is available at www.nature.com/reprints.

Publisher's note Springer Nature remains neutral with regard to jurisdictional claims in published maps and institutional affiliations.

\begin{abstract}
(c) (i) Open Access This article is licensed under a Creative Commons Attribution 4.0 International License, which permits use, sharing, adaptation, distribution and reproduction in any medium or format, as long as you give appropriate credit to the original author(s) and the source, provide a link to the Creative Commons licence, and indicate if changes were made. The images or other third party material in this article are included in the article's Creative Commons licence, unless indicated otherwise in a credit line to the material. If material is not included in the article's Creative Commons licence and your intended use is not permitted by statutory regulation or exceeds the permitted use, you will need to obtain permission directly from the copyright holder. To view a copy of this licence, visit http://creativecommons.org/licenses/by/4.0/.
\end{abstract}

(C) The Author(s) 2021 